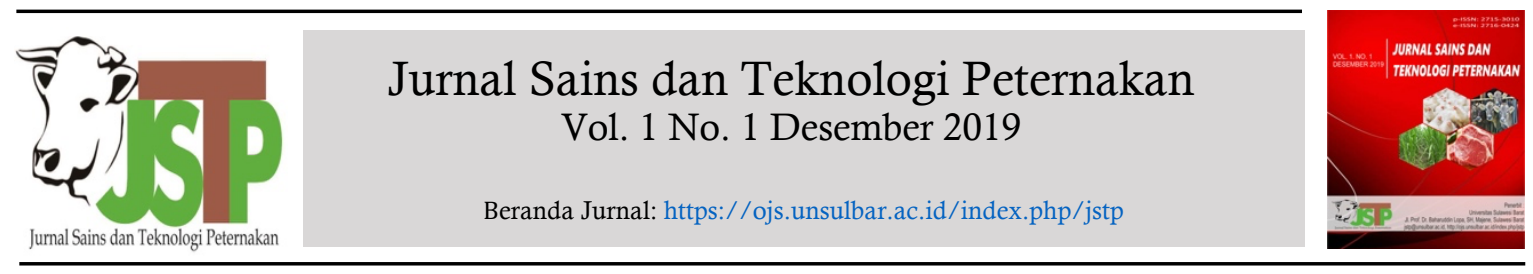

\title{
Performa Ayam Arab dengan Pemberian Energi-Protein pada Level Berbeda
}

\author{
(Arabic Chicken (Gallus turcicus) Performance with Different Dietary Energy-Protein level) \\ Windawati Alwi ${ }^{1 *}$, Laily Agustina ${ }^{1}$, Muhammad Zain Mide ${ }^{1}$ \\ ${ }^{1}$ Nutrisi dan Makanan Ternak, Fakultas Peternakan, Universitas Hasanuddin, J1. Perintis Kemerdekaan Km.10 \\ Makassar 90245
}

\section{A R T I C L E I N F O}

Received: 10 September 2019

Accepted: 23 Oktober 2019

*Corresponding author windawatia@gmail.com

Keywords:

Arabic chicken

Energy

Performance

Protein

Kata Kunci:

Ayam arab

Energi

Performa

Protein

\section{A B S T R A C T}

This research aimed to determine the effect of different energy and protein level giving in Arabic chicken on feed consumption, egg production and feed conversion. The materials used for this experiment were 80 heads of arabic chicken 5 months age and maintained for 6 weeks (36 days). The method used was completely randomized design (CRD) which consists of 4 treatments and 10 replications that R1 (protein $15 \%$ and EM 2500 Kcal), R2 (protein $16 \%$ and EM $2600 \mathrm{Kcal}$ ), R3 (protein $17 \%$ and EM $2700 \mathrm{Kcal}$ ) and R4 (protein $18 \%$ and EM $2800 \mathrm{Kcal}$ ). Analysis of variance showed that treatment significantly $(\mathrm{P}<0.05)$ on feed consumption, egg production and feed conversion. It could be concluded that more increasing energy and protein, the higher egg production, feed consumption and generates optimal feed conversion. Energy and protein with a protein level of $18 \%$ and energy $2800 \mathrm{Kcal} / \mathrm{kg}$ showed better performance.

\section{A B S T R A K}

Penelitian ini bertujuan untuk mengetahui pengaruh pemberian energi dan protein yang berbeda pada ayam arab terhadap konsumsi pakan, produksi telur dan konversi pakan. Materi yang digunakan pada penelitian ini adalah ternak ayam arab petelur fase layer umur 5 bulan sebanyak 80 ekor dan dipelihara selama 6 minggu (36 hari). Metode penelitian yang dilakukan menggunakan Rancangan Acak Lengkap (RAL) yang terdiri dari 4 perlakuan dan 10 ulangan yaitu R1 (Protein $15 \%$ dan EM 2.500 Kkal), R2 (Protein $16 \%$ dan EM $2600 \mathrm{Kkal}$ ), R3 (Protein $17 \%$ dan EM 2.700 Kkal) dan R4 (Protein $18 \%$ dan EM $2.800 \mathrm{Kkal}$ ). Analisis ragam menunjukkan bahwa perlakuan berpengaruh nyata $(\mathrm{P}<0,05)$ terhadap konsumsi pakan, produksi telur dan konversi pakan. Kesimpulan yang diperoleh bahwa semakin meningkat energi dan protein maka akan semakin tinggi produksi telur, konsumsi pakan dan konversi pakan akan optimal. Energi dan protein dengan level protein $18 \%$ dan energi $2.800 \mathrm{Kkal} / \mathrm{kg}$ memberikan performa terbaik. 


\section{Pendahuluan}

Ayam arab merupakan ayam buras yang memiliki performa cukup bagus dalam produksi telur. Produksi telur ayam arab lebih tinggi dibandingkan ayam buras yang lain. Terdapat dua jenis yaitu ayam arab silver (brakel kriel silver) dan merah atau golden (brakel kriel gold). Memproduksi telur 190 - 250 butir/tahun dengan rataan bobot telur $30-35 \mathrm{~g} /$ butir. Konsumsi pakan juga cukup efisien sebab bobot badannya yang kecil. Selain itu ayam arab tidak memerlukan waktu untuk mengeram sehingga dapat menghasilkan telur lebih banyak (Indra, Achmanu, \& Nurgiartiningsih, 2013).

Performa ayam arab dapat dilihat dari konsumsi pakan, produksi telur dan konversi pakan. Pemberian energi dan protein penentu terhadap performa ayam, karena naluri ayam akan berhenti makan bila kebutuhan energinya terpenuhi. Jadi dengan adanya keseimbangan antara energi-protein yang tepat maka performa yang dihasilkan ayam akan optimal. Varianti, Atmomarsono, \& Mahfudz (2017), menyatakan ayam menggunakan pakan untuk memenuhi segala kebutuhan nutrisi baik untuk pertumbuhan maupun produksi. Standar kebutuhan nutrisi protein ayam lokal di Indonesia masih beragam, dan belum diketahui secara pasti.

Pemberian energi dan protein pada pakan unggas akan mempengaruhi konsumsi pakan, produksi telur dan konversi pakan ayam arab. Nutrisi yang baik akan memberikan hasil yang baik untuk produksi telur. Penelitian tentang patokan kebutuhan energi-protein ayam buras terutama ayam arab masih beragam, sedangkan energi dan protein merupakan faktor penentu keberhasilan produktivitas ayam arab. Oleh karena itu, perlu dilakukan penelitian mengenai performa ayam arab terhadap konsumsi pakan, produksi telur dan konversi pakan dengan pemberian energi dan protein pada level berbeda untuk mengetahui kebutuhan ayam arab yang sesuai.

\section{Materi dan Metode}

\subsection{Materi}

Materi yang digunakan pada penelitian ini adalah ternak ayam arab petelur fase layer umur 5 bulan sebanyak 80 ekor, kandang cages terdiri dari 40 petak dengan ukuran panjang $30 \mathrm{~cm} \times$ lebar $35 \mathrm{~cm} \times$ tinggi $33 \mathrm{~cm}$, timbangan neraca jarum (Five Goats ${ }^{\circledR}$, Cina) berskala $0,05 \mathrm{~kg}$ dengan kapasitas $15 \mathrm{~kg}$ untuk menimbang ransum, ember, tempat ransum, tempat minum dan alat kebersihan.

\subsection{Metode}

\subsubsection{Rancangan Penelitian}

Rancangan yang digunakan dalam penelitian adalah Rancangan Acak Lengkap (RAL) dengan 4 perlakuan dan 10 ulangan, masing-masing unit percobaan terdiri dari 2 ekor ayam, sehingga jumlah ayam arab petelur yang digunakan adalah 80 ekor. Komposisi perlakuan sebagai beriku:

R1:Ransum dengan kandungan protein $15 \%$ dengan energi metabolisme $2.500 \mathrm{Kkal} / \mathrm{kg}$,

R2: Ransum dengan kandungan protein $16 \%$ dengan energi metabolisme $2.600 \mathrm{Kkal} / \mathrm{kg}$,

R3: Ransum dengan kandungan protein $17 \%$ dengan energi metabolisme $2.700 \mathrm{Kkal} / \mathrm{kg}$,

R4: Ransum dengan kandungan protein $18 \%$ dengan energi metabolisme $2.800 \mathrm{Kkal} / \mathrm{kg}$.

\subsubsection{Pemeliharaan}

Day Old Chick (DOC) diperoleh dari Sukabumi dipelihara sampai umur 5 bulan dengan pemberian ransum jagung kuning, dedak dan konsentrat RK 24 dari PT. Charoen Pokphand Indonesia. Setelah berumur 5 bulan, ayam arab sebanyak 80 ekor ditempatkan secara acak pada cages dengan ukuran panjang $30 \mathrm{~cm} \times$ lebar $35 \mathrm{~cm} \times$ tinggi $33 \mathrm{~cm}$ dan dipelihara selama 36 hari. Ayam diberikan ransum dan air minum secara ad-libitum setiap hari. Kandungan nutrisi pakan dapat dilihat pada Tabel 1. Ransum yang diberikan terdiri dari jagung kuning, dedak dan konsentrat RK 24 dengan perlakuan yang berbeda (Tabel 2).

Tabel 1. Kandungan nutrisi bahan pakan

\begin{tabular}{|c|c|c|c|c|}
\hline \multirow{2}{*}{\multicolumn{2}{|c|}{ Zat gizi }} & \multicolumn{3}{|c|}{ Jenis Pakan } \\
\hline & & Jagung $^{(1)}$ & Dedak $^{(1)}$ & Konsentrat \\
\hline \multicolumn{2}{|c|}{ ME (Kkal/kg) } & 3.430 & 1.630 & $3.974^{(2)}$ \\
\hline \multicolumn{2}{|c|}{ Protein Kasar (\%) } & 9 & 12 & $36,59^{(2)}$ \\
\hline \multicolumn{2}{|c|}{ Lemak Kasar (\%) } & 2,5 & 8,2 & $8^{(3)}$ \\
\hline \multicolumn{2}{|c|}{ Serat Kasar (\%) } & 3,8 & 7,9 & $3^{(3)}$ \\
\hline \multicolumn{2}{|c|}{$\mathrm{Ca}(\%)$} & 0,02 & 0,12 & $10^{(3)}$ \\
\hline \multicolumn{2}{|l|}{$\mathrm{P}(\%)$} & 0,1 & 0,5 & $1,1^{(3)}$ \\
\hline \multirow[t]{2}{*}{ Sumber: } & (1)Anggo & di $\quad(1985$ & ); $\quad{ }^{(2)} \mathrm{Ha}$ & Analisis \\
\hline & $\begin{array}{l}\text { Laborato } \\
\text { Perternak } \\
{ }^{(3)} \text { Kandun } \\
\text { Petelur P' }\end{array}$ & $\begin{array}{l}\text { um Kimia } \\
\text { on Universi }\end{array}$ & $\begin{array}{l}\text { Makanan T } \\
\text { tas Hasanu }\end{array}$ & $\begin{array}{l}\text { aak Fakultas } \\
\text { Idin (2013); } \\
\text { Intuk Ayam }\end{array}$ \\
\hline
\end{tabular}

\subsubsection{Variabel yang Diamati}

\section{Produksi Telur/Hen Day Production (\%)}

Produksi telur dihitung setiap hari selama penelitian. Rumus yang digunakan untuk menghitung produksi telur harian (North, 1984) sebagai berikut:

Hen Day Production $=\frac{\text { Jumlah produksi telur }}{\text { Jumlah ayam yang ada }} \times 100 \%$ 
Tabel 2. Komposisi bahan pakan dan kandungan nutrisi dalam ransum

\begin{tabular}{|c|c|c|c|c|}
\hline \multirow{2}{*}{ Komposisi Bahan Pakan (\%) } & \multicolumn{4}{|c|}{ Perlakuan } \\
\hline & R1 & $\mathrm{R} 2$ & R3 & $\mathrm{R} 4$ \\
\hline Jagung & 29 & 29 & 29 & 29 \\
\hline Dedak & 55 & 51 & 47 & 43 \\
\hline Konsentrat & 16 & 20 & 24 & 28 \\
\hline Total & 100 & 100 & 100 & 100 \\
\hline \multicolumn{5}{|l|}{ Komposisi Zat Nutrisi } \\
\hline Energi Metabolisme (Kkal/kg) & $2.527,04$ & $2.620,8$ & $2.714,56$ & $2.808,32$ \\
\hline Protein Kasar (\%) & 15,0644 & 16,048 & 17,0316 & 8,0152 \\
\hline Lemak Kasar (\%) & 5,927 & 5,731 & 5,535 & 5,339 \\
\hline Serat Kasar (\%) & 6,515 & 6,507 & 6,499 & 6,491 \\
\hline Calsium $(\%)$ & 1,6718 & 2,067 & 2,4622 & 2,8574 \\
\hline Posfor (\%) & 0,48 & 0,504 & 0,528 & 0,552 \\
\hline $\begin{array}{ll}\text { Keterangan: } & \text { R1: Ransum deng } \\
& \text { kandungan protei } \\
& 17 \% \text { dengan ener } \\
& \text { metabolisme } 2.800\end{array}$ & $\begin{array}{l}\text { in } 15 \% \mathrm{~d} \\
\text { gi metabo } \\
0 \mathrm{Kkal} / \mathrm{kg}\end{array}$ & $\begin{array}{l}\text { i metabol } \\
\mathrm{Kkal} / \mathrm{kg} \\
\text { im denga }\end{array}$ & $\begin{array}{l}\mathrm{Kkal} / \mathrm{kg} ; \\
\mathrm{m} \text { dengan } \\
\text { in protein }\end{array}$ & $\begin{array}{l}\text { Im dengan } \\
\text { an protein } \\
\text { gan energi }\end{array}$ \\
\hline
\end{tabular}

\section{Konsumsi Pakan}

Jumlah konsumsi pakan dihitung dengan cara menimbang pakan yang diberikan setiap minggu dikurangi pakan sisa pada akhir minggu. Konsumsi pakan diketahui berdasarkan rumus (Rasyaf, 1994) sebagai berikut:

Konsumsi pakan g/ekor/minggu $=\frac{\text { Pakan yang diberikan }(\mathrm{g})-\text { Pakan Sisa }(\mathrm{g})}{\text { Jumlah ayam (Ekor) }}$

\section{Konversi Pakan}

Konversi ransum adalah angka yang menunjukkan kemampuan ayam untuk mengubah sejumlah pakan menjadi setiap $\mathrm{kg}$ produksi telur dalam satuan waktu tertentu. Konversi pakan menunjukkan gambaran tentang efisiensi penggunaan pakan ditinjau dari efisiensi teknis. Rumus konversi pakan berdasarkan (Rasyaf, 1997) adalah:

$$
\text { Konversi ransum }=\frac{\text { Konsumsi Pakan }(\mathrm{kg})}{\text { Produksi telur }(\mathrm{kg})}
$$

\subsection{Analisis Data}

Data yang diperoleh dianalisis dengan menggunakan RAL (Rancangan Acak Lengkap), perlakuan yang berpengaruh nyata, dilanjutkan dengan Uji Beda Nyata Terkecil (BNT) (Gaspersz, 1991).

\section{Hasil dan Pembahasan}

Rataan konsumsi pakan, produksi telur dan konversi pakan ayam arab yang mendapat ransum dengan energi dan protein pada level yang berbeda dapat dilihat pada Tabel 3 .

\subsection{Konsumsi Pakan}

Berdasarkan analisis ragam data penelitian menunjukkan bahwa pemberian energi dan protein dengan level berbeda berpengaruh nyata $(\mathrm{P}<0,05) \quad$ terhadap konsumsi pakan. Konsumsi pakan R4 (Protein $18 \%$ dan energi $2.800 \mathrm{Kkal} / \mathrm{kg}$ ) merupakan konsumsi tertinggi (84,88 g/ekor/hari). Hal ini menunjukkan bahwa semakin tinggi imbangan energi-protein pakan maka kecukupan energiprotein untuk kebutuhan hidup pokok dan produksi akan semakin baik. (Ariesta, Mahardika, \& Dewi (2015) yang menyatakan bahwa energi-protein yang rendah menyebabkan semakin rendah protein yang dicerna. Selain itu faktor yang mempengaruhi adalah palatabilitas. Nuningtyas (2014) menyatakan bahwa satu diantara banyak faktor yang memengaruhi tingginya tingkat konsumsi pakan adalah palatabilitas. Palatabilitas merupakan tingkat kesukaan ternak terhadap pakan. Hal ini juga sesuai pernyataan Astuti (2012) bahwa beberapa faktor yang memengaruhi konsumsi pakan antara lain umur, ukuran tubuh, palatabilitas, dan kualitas pakan yang diberikan. Palatabilitas bergantung pada beberapa hal seperti penampilan, bentuk pakan, bau, rasa, tekstur, dan suhu lingkungan (Kestaria, Nur, \& Malik, 2016).

Tabel 3. Rataan produksi telur, konsumsi pakan dan konversi pakan ayam arab

\begin{tabular}{|c|c|c|c|c|}
\hline \multirow{2}{*}{ Parameter } & \multicolumn{4}{|c|}{ Perlakuan } \\
\hline & $\mathrm{R} 1$ & R2 & R3 & R4 \\
\hline Konsumsi Pakan (g/ekor/hari) & $81,35 \pm 4,38^{a}$ & $77,38 \pm 4,64^{b}$ & $82,04 \pm 3,14^{\mathrm{a}}$ & $84,88 \pm 1,59^{a}$ \\
\hline Produksi Telur (\% Hen Day) & $40,28 \pm 4,32^{\mathrm{a}}$ & $49,38 \pm 9,27^{b}$ & $52,16 \pm 10,28^{b c}$ & $58,33 \pm 8,33^{c}$ \\
\hline Konversi Pakan & $3,73 \pm 1,39^{a}$ & $2,77 \pm 0,38^{b}$ & $2,8 \pm 0,41^{\mathrm{b}}$ & $2,76 \pm 0,34^{b}$ \\
\hline
\end{tabular}

Keterangan: Superskrip yang berbeda pada baris yang sama menunjukkan berbeda nyata $(\mathrm{P}<0,05)$. R1: Ransum dengan kandungan Protein $15 \%$ dan EM $2.500 \mathrm{Kkal} / \mathrm{kg}$; R2: Ransum dengan kandungan Protein 16\% dan EM 2.600 $\mathrm{Kkal} / \mathrm{kg}$; R3: Ransum dengan kandungan Protein 17 \% dan EM $2.700 \mathrm{Kkal} / \mathrm{kg}$; dan R4: Ransum dengan kandungan Protein $18 \%$ dan EM $2.800 \mathrm{Kkal} / \mathrm{kg}$. 
Uji BNT terhadap perlakuan diperoleh hasil bahwa perlakuan $\mathrm{R} 2$ berbeda nyata $(\mathrm{P}<0,05)$ terhadap perlakuan R1, R2 dan R3, sedangkan perlakuan R1, R3 dan R4 tidak terdapat perbedaan yang signifikan. Hal ini menunjukkan bahwa komposisi pakan pada perlakuan R2 dengan jumlah dedak sekitar $51 \%$ menyebabkan ayam merasa cepat kenyang. Meskipun R1 jumlah dedaknya $55 \%$ namun jumlah konsumsi terendah adalah pakan R2. Komposisi dedak ini menyebabkan konsumsi menurun. Trisiwi (2015) melaporkan bahwa semakin tinggi penggunaan dedak padi menurunkan jumlah konsumsi pakan. Hal ini juga disebabkan karena selera individu ayam yang berbeda. Selera ayam berhubungan dengan rasa lapar. Selera merangsang pusat saraf (hyphotalamus) pada bagian lateral yang menstimulasi keadaan lapar. Beberapa faktor yang memengaruhi pusat saraf yaitu lipostatik, aminostatik dan glukostatik. Hal ini sesuai pendapat Agustina \& Purwanti (2012) bahwa karbohidrat, lemak dan protein, serta zatzat pembawa cita rasa dan aroma (flavor) akan diterima oleh sistem penerima perangsang metabolit dan dapat menimbulkan perubahan selera makan secara fisik.

Kandungan serat kasar yang tinggi menyebabkan ayam cepat kenyang (bulky). Pakan yang bersifat bulky berpengaruh terhadap tembolok, dimana di dalam tembolok terjadi distensi pada saraf-saraf yang akan menghantarkan impuls ke hipotalamus agar menghentikan konsumsi ayam. Nurhayati (2010) menyatakan kandungan serat kasar mengakibatkan ayam cepat merasa kenyang sehingga terjadi penurunan konsumsi ransum karena serat kasar bersifat bulky. Serat kasar yang tinggi juga menyebabkan energi yang dibutuhkan untuk mencernanya menjadi lebih banyak. Noferdiman, Lisna, \& Yusma (2017) menyatakan bahwa serat kasar akan berdampak pada konsumsi yang cenderung menurun. Hal ini disebabkan karena terbatasnya tembolok dalam menampung makanan karena kerapatan jenis yang rendah.

\subsection{Produksi Telur}

Berdasarkan analisis ragam diperoleh hasil bahwa pemberian energi dan protein dengan level berbeda berpengaruh nyata $(\mathrm{P}<0,05)$ terhadap produksi telur ayam arab. Semakin tinggi imbangan energi-protein yang diberikan pada ayam arab maka semakin tinggi pula produksi telurnya (Hen Day Production). Hal ini sesuai dengan pendapat Lengkong, Leke, Tangkau, \& Sane (2015) yang menyatakan dalam upaya peningkatan produksi telur, ternak unggas harus diberi pakan sesuai kebutuhan dan mengandung gizi sesuai rekomendasi. Produksi telur sangat erat kaitannya dengan konsumsi pakan, konversi pakan. Pemberian pakan yang baik tentunya akan berpengaruh terhadap produksi telur, konsumsi pakan, dan juga angka konversi dari pakan yang diberikan. Santoso \& Fitasari (2016) menyatakan pertumbuhan dan produksi ternak yang maksimal dapat tercapai apabila dari segi kualitas pakan mampu menyuplai unsur-unsur nutrisi yang dibutuhkan ternak, serta dari segi kuantitas pemberian pakan dilakukan berdasarkan total kebutuhan nutrisi yang berasal dari bahan pakan yang dibutuhkan oleh ternak.

Uji BNT terhadap perlakuan diperoleh hasil bahwa pada perlakuan R1 produksi telur nyata lebih rendah $(\mathrm{P}<0,05)$ dari perlakuan $\mathrm{R} 2$, $\mathrm{R} 3$ dan $\mathrm{R} 4$. Ini disebabkan pada perlakuan $\mathrm{R} 1$ jumlah protein $15 \%$ dengan energi metabolisme 2.500 $\mathrm{Kkal} / \mathrm{kg}$ belum cukup untuk memenuhi kebutuhan produksi. Semakin tinggi produksi telur maka dibutuhkan banyak energi dan protein untuk memproduksi telur. Nuningtyas (2014) menyatakan bahwa kandungan protein dan energi semakin meningkat dengan semakin tingginya level penggunaan pakan yang menunjukkan bahwa kandungan zat makanan mempunyai keterkaitan antara protein dan energi. Energi dibutuhkan ayam untuk beraktivitas, tumbuh, dan berproduksi. Produksi telur dapat dipengaruhi oleh faktor jumlah pakan yang dikonsumsi ayam, umur, genetik, kesehatan ayam dan lingkungan (Ramadhan, Mahfudz, \& Sarengat, 2018).

Hasil penelitian ini serupa dengan penelitian Rizal et al. (2015) bahwa Hen Day Production ayam arab berkisar antara 42,13\% $0,93 \%$. Semakin tinggi level energi-protein yang diberikan maka akan semakin tinggi produksi telur yang dihasilkan dan semakin rendah level energi-protein sehingga produksi telur juga akan rendah. Tugiyanti \& Iriyanti (2012) menyatakan bahwa kuantitas dan kualitas pakan yang diberikan pada ternak sangat menentukan produksi dan kualitas telur baik secara internal maupun eksternal.

\subsection{Konversi Pakan}

Pakan yang memiliki konversi paling tinggi adalah perlakuan R1 dan terendah perlakuan R4. Hal ini disebabkan oleh jumlah produksi (output) perlakuan R1 lebih sedikit dibandingkan jumlah konsumsi (input) sebaliknya pada perlakuan $\mathrm{R} 4$ jumlah produksi (output) sebanding dengan jumlah konsumsi (input), sehingga lebih efisien. Hal ini sesuai dengan pendapat Sawadi, Hafid, \& 
Nafiu (2016) menyatakan bahwa semakin baik mutu ransum, maka semakin kecil pula konversi ransumnya. Baik tidaknya mutu ransum ditentukan oleh seimbang tidaknya kebutuhan zat gizi pada ransum itu.

Uji BNT terhadap perlakuan diperoleh hasil bahwa konversi pakan perlakuan R1 berbeda nyata $(\mathrm{P}<0,05)$ terhadap perlakuan $\mathrm{R} 2, \mathrm{R} 3$ dan R4. Perlakuan R2, R3 dan R4 tidak terdapat perbedaan yang signifikan. Hal ini menunjukkan bahwa konversi pakan yang terbaik adalah R4 (Protein $18 \%$ dan energi $2.800 \mathrm{Kkal} / \mathrm{kg}$ ) dengan produksi telur yang dihasilkan oleh perlakuan R4 lebih banyak. Hal ini sesuai dengan penelitian Al-Khalifa \& Al-Nasser (2012) bahwa level protein yang direkomendasikan untuk ayam arab adalah $18 \%$.

Pada penelitian ini juga dilaporkan bahwa konversi ransum pada level protein $18 \%$ adalah dengan kisaran 2,43-2,76. Nubatonis, Nalley, \& Hine (2018) menyatakan bahwa konversi ransum erat kaitannya dengan konsumsi ransum dan produksi telur, semakin kecil nilai konversi pakan maka semakin efisien produksi ternak.

Konversi pakan tertinggi pada perlakuan R1 yang merupakan pakan energi-protein paling rendah dari perlakuan yang lain menunjukkan bahwa ransum tersebut kurang efisien diberikan pada ternak unggas. Pakan R4 lebih efisien digunakan untuk menghasilkan produksi telur yang optimal. Pernyataan tersebut sesuai dengan pendapat Ramadhan et al. (2018) yang menyatakan bahwa pakan dapat digunakan sebagai gambaran koefisien produksi, semakin rendah nilai konversi pakan maka akan semakin baik produksinya, begitu pula sebaliknya, semakin tinggi nilai konversi pakan maka semakin kurang baik efisiensi penggunaan pakan untuk produksinya. Risnajati (2014) menyatakan bahwa beberapa hal yang dapat mempengaruhi nilai konversi pakan antara lain kondisi lingkungan kandang, manajemen pemeliharaan termasuk manajemen pemberian pakan, produksi telur serta konsumsi pakan hariannya.

\section{Kesimpulan}

Penelitian ini menunjukkan bahwa semakin meningkat energi-protein ransum pada ayam arab maka produksi telur akan semakin tinggi, dengan konsumsi pakan dan konversi pakan yang optimal. Pemberian ransum dengan level protein $18 \%$ dan energi $2.800 \mathrm{Kkal} / \mathrm{kg}$ memberikan performa terbaik.

\section{Daftar Pustaka}

Agustina, L., \& Purwanti, S. (2012). Ilmu Nutrisi
Unggas. Solo: Rumah Pengetahuan.

Al-Khalifa, H., \& Al-Nasser, A. (2012). Effect of different protein levels on Arabi chicken performance. International Journal of Poultry Science, 11(11), 706-709.

Anggorodi, R. (1985). Ilmu Makanan Ternak Unggas. Jakarta: Universitas Indonesia.

Ariesta, A. H., Mahardika, I. G., \& Dewi, G. (2015). Pengaruh level energi dan protein ransum terhadap penampilan ayam kampung umur 0-10 minggu. Majalah Ilmiah Peternakan, 18(3), 89-94.

Astuti, N. (2012). Kinerja ayam kampung dengan ransum berbasis konsentrat Broiler. Jurnal Agrisains, 3(5), 51-58.

Gaspersz, V. (1991). Metode dan Rancangan Percobaan. Bandung: Americo.

Indra, G. K., Achmanu, \& Nurgiartiningsih, A. (2013). Performans produksi ayam arab (Gallus turcicus) berdasarkan warna bulu. Jurnal Ternak Tropika, 14(1), 8-14.

Kestaria, Nur, H., \& Malik, B. (2016). Pengaruh substitusi pakan komersil dengan tepung ampas kelapa terhadap performa ayam kampung. Jurnal Peternakan Nusantara, 2(1), 43-48.

Lengkong, E. M., Leke, J. R., Tangkau, L., \& Sane, S. (2015). Substitusi sebagian ransum dengan tepung tomat merah (Solanum lycopersicum $L$ ) terhadap penampilan produksi ayam ras petelur. ZOOTEC, 35(2), 247-257. https://doi.org/10.35792/zot. 35.2.2015.8362

Noferdiman, Lisna, \& Yusma, D. (2017). Penggunaan tepung Azola microphilla dan enzim selulase dalam ransum terhadap penampilan produksi dan nilai ekonomis itik lokal Kerinci jantan. Prosiding Seminar Nasional VI HITPI "Peran Strategis Tumbuhan Pakan Dalam Mendukung UPSUS SIWAB Untuk Mewujudkan Ketahanan Pangan," 31-39. Jambi: Fapet Press, Universitas Jambi.

North, M. O. (1984). Breeder Management. In Commercial Chicken Production Manual (3rd ed.). Westport, Connecticut: AVI publishing Co. Ltd.

Nubatonis, A., Nalley, W. M., \& Hine, T. M. (2018). Efektivitas ekstrak hipofisa sapi terhadap produktivitas ayam Petelur (Gallus gallus) afkir strain Hisex Brown. Jurnal Sain Peternakan Indonesia, 13(3), 244- 
251. https://doi.org/10.31186/jspi.id.13. 3.244-251

Nuningtyas, Y. F. (2014). Pengaruh penambahan tepung bawang putih (Allium sativum) sebagai aditif terhadap penampilan produksi ayam pedaging. Jurnal Ternak Tropika, 15(1), 65-73.

Nurhayati. (2010). Pengaruh penggunaan tepung buah mengkudu terhadap bobot organ pencernaan ayam pedaging. Jurnal Agripet, 10(2), 40-44. https://doi.org/10.17969/ agripet.v10i2.643

Ramadhan, M., Mahfudz, L. D., \& Sarengat, W. (2018). Performans Ayam Petelur Tua dengan Penggunaan Tepung Ampas Kecap dalam Pakan. Jurnal Sain Peternakan Indonesia, 13(1), 84-88. https://doi.org/10. 31186/jspi.id.13.1.84-88

Rasyaf, M. (1994). Manajemen Peternakan Ayam Kampung. Yogyakarta: Kanisius.

Rasyaf, M. (1997). Penyajian Makanan Ayam Petelur. Jakarta: Penebar Swadaya.

Risnajati, D. (2014). Pengaruh jumlah ayam per induk buatan terhadap performan ayam petelur strain isa brown periode starter. Sains Peternakan: Jurnal Penelitian Ilmu Peternakan, 12(1), 10-14. https://doi.org/ $10.20961 /$ sainspet.v12i1.4866

Rizal, Y., Nuraini, Mirnawati, Mahata, M. E., Darman, R., \& Kurniawan, D. (2015). Production performance of Gold Arab laying-hens fed diet containing Neurospora crassa fermented palm kernel cake. International Journal of Poultry Science, 14(12), 628-632.

Santoso, E. P., \& Fitasari, E. (2016). Pengaruh pemberian pakan dengan level protein yang berbeda terhadap energi metabolisme ayam Kampung. Buana Sains, 16(1), 17-24. https://doi.org/10.33366/bs.v16i1.407

Sawadi, M., Hafid, H., \& Nafiu, L. O. (2016). Pengaruh bobot potong dan pakan komersial terhadap pertumbuhan ayam Broiler. Jurnal Ilmu Dan Teknologi Peternakan Tropis, 3(3), 47-56. https://doi. org/10.33772/jitro.v3i3.2569

Trisiwi, H. F. (2015). Pengaruh kandungan dedak padi dan level energi pakan terhadap penampilan ayam kampung single comb. Jurnal Pertanian Agros, 17(1), 64-70.

Tugiyanti, E., \& Iriyanti, N. (2012). Kualitas eksternal telur ayam petelur yang mendapat ransum dengan penambahan tepung ikan fermentasi menggunakan isolat produser antihistamin. Jurnal Aplikasi Teknologi Pangan, 1(2), 44-47.

Varianti, N. I., Atmomarsono, U., \& Mahfudz, L. D. (2017). Pengaruh pemberian pakan dengan sumber protein berbeda terhadap efisiensi penggunaan protein ayam lokal persilangan. Jurnal Agripet, 17(1), 53-59. https://doi.org/10.17969/agripet.v17i1.72 57 